\title{
Engineering president is stripped of duties
}

Washington. Harold Liebowitz, the embattled and recently elected president of the US National Academy of Engineering, has been relieved of his principal responsibility, acting as vice chair of the National Research Council. The move makes his resignation or forced removal likely in the near future.

In a highly unusual decision, the council of the National Academy of Sciences (NAS) unanimously approved a vote of no confidence in Liebowitz at a meeting two weeks ago, and ordered him to stop conducting business on behalf of the NRC. The NAS charter gives it ultimate legal responsibility for the research council, which is jointly administered by the two academies and the Institute of Medicine.

In a terse statement issued after the meeting, the NAS council said it has noted "with great concern" what it described as Liebowitz's "failure to follow approved procedures of the Research Council, and his adverse impact on Research Council staff productivity and morale".

Liebowitz, who is 71 and a former dean of engineering at George Washington University, took office last July, after narrowly beating a candidate endorsed by the NAE's own nominating committee. He had run for election on an outsider's platform, promising to reform what he viewed as the hidebound Washington bureaucracy that administers the 32-year-old NAE, which provides advice on engineering matters to the federal government. He also vowed to get more of the academy's 1,800 members involved in its activities.

But Liebowitz's problems since taking office have had less to do with his reformist zeal than with his personal behavior, which sources both inside and outside the academy say has been erratic, confused, and unprofessional. Particularly troubling to the NAS has been his unwillingness or inability to follow rules governing the NRC's dealings with outside organizations, including how it accepts money from government agencies to conduct research studies.

The NAE's own governing council, recognizing problems with their new president almost immediately, curtailed Liebowitz's spending authority and his authority over NAE staff last September, when he had been in office less than three months. But according to NAE and NAS staff members, the aberrant behaviour continued; they are reluctant to give details, partly from fear of possible lawsuits by Liebowitz should he be forced out of office.

After watching the events at its sister organization with mounting concern, the NAS stepped in last week when it concluded Liebowitz had become an embarrassment and a threat to the NRC's integrity. An even terser statement released last week by the Academy of Engineering council stated that

the NAE council "understands the reasons for the NAS Resolution, and its importance to both academies," and was "determining the actions it should take". It promised to inform the members of the NAE of its conclusions "in the near future".

At the beginning of this week, the council's options were still unclear: NAE by-laws contain no specific provision for removing an elected officer, although they appear to allow the council to relieve the president of his duties.

As for Liebowitz, he says he has every intention of serving out his six-year term. In a statement issued on Monday (26 Febru-

\section{Genome laboratory makes its mark}

Kazusa, Japan. In a major coup for a young, regional laboratory, the Kazusa DNA Research Institute in Chiba Prefecture east of Tokyo has sequenced the entire genome of a blue-green algae (cyanobacterium) in less than a year. This achievement has surprised many universitybased researchers in Japan, whose own sequencing efforts have been hampered by government restrictions on the hiring of technicians, as well by as a general lack of funds.

The sequence of the bacterium's entire 3.5-megabase genome will be presented in a paper to be delivered to an international workshop on genomic structure and function in Makuhari in Chiba next month.

Kenichi Matsubara of Osaka University, the leader of Japan's human genome project, says that the group's achievement is very significant for Japanese science. He adds that the results will probably be very significant for plant research as well, given the close relationship between cyanobacteria and plant chloroplasts.

The Kazusa DNA Institute was established by the Chiba prefectural government in October 1994 as the first dedicated genomic research institute in Japan (see Nature 372, 3; 1994). Some academics have disparaged the institute and its work as merely a "local effort". But its success in sequencing the cyanobacterium's genome in less than a year has now silenced the critics.

The institute employs 30 scientists and 30 technicians who, in addition to the cyanobacterium work, have also been sequencing large fragments of human cDNA and developing new sequencing technologies. Mitsuru Takanami, director of the institute, says that future plans include sequencing the genome of higher plants.

Michio Oishi, director of the Ministry of International Trade and Industry's (MITI) Institute for Bioscience and ary), he described the NAS resolution as an attempt to "thwart efforts of the NAE president to correct management procedures in the NRC and NAE" and to pursue goals relating to engineering education.

But, having already been relieved of his most important duty, Liebowitz appeared to be in an untenable position. One NAE official said that he expected members of the academy to be asked to vote in a special election for president "sooner or later". The NAE council hopes to meet within the next fortnight to decide their next move in what the official calls a "delicate and very unpleasant situation".

Tony Reichhardt

Human Technology, and an adviser to the institute, attributes its success partly to financial flexibility, which has allowed technicians to be hired for the sequencing work, and partly to the focused nature of the institute's projects. Similar sequencing projects at universities are typically spread across several institutions, and staffed by students.

A project to sequence the genome of $E$. coli, which started in Japan in 1989, failed to progress as quickly as the project leaders originally planned because of inadequate funding and also because technicians cannot be hired on university research grants.

Katsumi Isono of Kobe University, who has continued sequencing the E.coli genome without direct government funding since 1991, says that repeated appeals to the Ministry of Education, Science, Sport and Culture (Monbusho) to allow hiring of personnel using university grants have been rejected. Very recently, however, Monbusho has indicated that it may establish a more flexible category of grant that will facilitate the hiring of research personnel.

Genomic research in both the public and private sectors has been slow to start in Japan. But recent large allocations from a number of ministries has helped to remedy this situation. In particular, MITI and the Ministry of Health and Welfare (MHW) have separate but related plans to cooperate with the private sector in establishing research institutes dedicated to the development and application of genomic technology and information (see Nature 378,$2 ;$ 1995).

The site for MITI's planned institute, the Helix Institute, will not be officially announced until next month. But the Kazusa DNA Institute is strongly tipped to house the new institute, and its latest success cannot have done its chances of doing so any harm.

Stephen Barker 